\title{
The Variable Characteristics and Response to Climatic Factors of the Runoff in the Downstream Areas of the Yellow River under the Background of Global Change
}

\author{
Mei Hong ${ }^{1, *}$, Dong Wang ${ }^{2}$, Wenhua Zeng ${ }^{1}$, Chenchen $\mathrm{Ma}^{3}$, Liang Zhao ${ }^{1}$ \\ ${ }^{I}$ Research Center of Ocean Environment Numerical Simulation, Institute of Meteorology and oceanography, PLA \\ University of Science and Technology, China \\ ${ }^{2}$ Department of Hydrosciences, School of Earth Sciences and Engineering, Nanjing University, China \\ ${ }^{3}$ Lianyungang Meteorological Bureau, Lianyungang 222006, China
}

Received 25 June 2015

Accepted 15 November 2015

\begin{abstract}
In this paper, the runoff of Huayuankou and Lijin Hydrologic Stations of the downstream areas of the Yellow River from 1951 to 2012 were calculated and analyzed in order to explore the runoff variable characteristics and their response to climatic factors. The following conclusions can be drawn:(1)Annual runoff of the river shows a clear downward trend as a whole, especially in the 1990s, but shifted to increase in the early 21 st century.(2)Runoff can be affected by climate change; climatic factors and runoff change in the same time or precedes the latter.(3)The response of runoff to climatic factors is not stable, in other words, changing with time; (4)the response of runoff to precipitation is more sensitive than that of temperature.(5)Precipitation and temperature both contribute to the change of runoff, but the former is a positive contribution and the latter is opposite.
\end{abstract}

Keywords: Downstream areas of the Yellow River, runoff change, climate change, response, quantitative analysis

\section{全球变化背景下黄河下游径流的变化特征及对气候因子的响应}

\author{
洪梅 $^{1}$, 王拣 ${ }^{2}$, 曾文华 ${ }^{1}$, 马晨晨 ${ }^{3}$, 赵亮 ${ }^{1}$ \\ 1. 解放军理工大学气象海洋学院军事海洋教研中心, 江苏 南京 211101 \\ 2. 南京大学地球科学与工程学院水科学系, 江苏 南京 210046 \\ 3. 连云港气象局, 江苏 连云港 222006
}

\begin{abstract}
摘要: 选取 1951-2012 年黄河流域下游两个水文站实测径流时间序列资料进行了统计分析和特征诊断。研究表明：1）近 60 年, 黄河流域下游的径流量总体呈明显下降趋势, 21 世纪之后转呈增长的趋势; 2) 径流年季变化峰型不同, 径流量主要 集中在汛期, 且 90 年代之后峰型较之前平缓；3）径流地域分布极不均匀, 越靠近黄河下游越不均匀；4）流域内气候增暖 效应明显, 降水总体呈减少趋势, 气候对径流影响显著且呈现时变特征; 5) 降水对径流以正贡献为主, 温度对径流以负贡 献为主, 且降水量正贡献绝对值高于温度负贡献绝对值。研究工作旨在为应对气候变化和我国水资源利用提供决策参考。
\end{abstract}

关键词: 黄河下游; 径流变化; 气候变化; 响应; 定量分析

\footnotetext{
${ }^{*}$ Corresponding author: flowerrainhm@126.com

资助项目：国家自然科学基金（No.41276088; No.41375002; No.41306010）资助
} 


\section{1. 引言}

径流是一定时期内, 流域中气候因素和下垫面 各种自然地理因素以及人类活动等综合作用的产物。 径流的形成过程是多种因素相互作用、相互联系的复 杂的自然现象, 径流的变化不仅影响着人类社会系统 的安全, 同时也影响着自然生态系统的健康(郝振纯 等, 2006; 徐东霞, 2008)。21 世纪, 全球经历着以 变暖为主要特征的变化过程。1880-2012 年全球平均 温度升高了 $0.85^{\circ} \mathrm{C}$, 且这种增暖趋势仍将持续。在 全球气候变暖背景下, 全球河川径流基本上呈现出下 降的趋势。IPCC 第四次评估报告（2007）预测, 到 21 世纪中期, 某些中纬度和热带干旱地区的河川年 平均径流将会减 10\%-30\%。

对黄河流域径流变化及其与气候、人类活动等因 素关系的研究 (蓝永超等, 2010) 表明: 气温升高和 降水减少导致黄河流域径流量总体呈减少趋势, 径流 量变化既有波动性特征, 又表现出一定的年际趋势, 且与气候因子变化关系密切。在全球变化背景下, 黄 河流域是气候变暖的显著区域, 空间上呈北高南低特 点, 气温的地区分布特点是由南向北、由东向西逐渐 降低, 尤以 20 世纪 80 年代以来, 黄河流域气温增暖 最为显著。 20 世纪 90 年代, 黄河流域降水减少最为 明显, 进入 21 世纪, 黄河流域降水略有增加趋势 （刘吉峰和范旻昊，2010）。气候变化对黄河流域径 流变化规律及其气候响应形式也将发生变化, 但相关 研究不多, 且偏重于定性分析, 对黄河中下游地区的 研究更为欠缺。

针对上述问题，本文拟基于黄河流域近 60a 的 实测径流资料和气象资料, 运用统计学等方法分析径 流在不同时间尺度上的变化特征、探讨径流与气候影 响因子的内在关联、诊断气候影响因子对径流变化的 贡献和机理, 为适应和应对气候变化, 合理规划水资 源利用提供科学依据。

\section{2. 径流的时间序列变化规律}

河川径流是一种非平稳信号, 并不存在真正意 义上的周期性, 而时而以这种周期变化, 时而以另一 周期变化, 并且同一时期又包含各种时间尺度的周期 变化, 在时域中存在多层次时间尺度结构和局部化特 征。采用 Morlet 小波变换对两站的年平均径流进行了 周期性分析。Morlet 小波变换的原理可以详见相关参 考文献（Grinsted and Moore，2004）。

黄河利津水文站是万里黄河上的最后一个水文 站, 黄河水务的封笔之作。黄河利津水文站建于 1934 年 6 月, 1937 年 11 月因抗站停测。解放后, 1950 年 1 月重新设站, 现归黄委会山东水文水资源局 管理。黄河花园口水文站设立于 1938 年 7 月, 上距
河源约 4700 公里, 下距河口 770 公里, 集水面积 73 万平方公里, 占黄河流域总面积的 $97 \%$, 是黄河最重 要的水沙控制站。这两个水文站的主要任务是：控制 黄河入海水、沙量，为黄河下游防洪、防凌、水资源 统一调度提供水情: 研究和探索水文要素变化规律, 为黄河下游河道治理、水沙资源利用以及黄河三角洲 开发等搜集水文资料：对外承担各类水文测验项目， 地形、河道测量等。所以本文选用这两个站点来对其 径流和气候因子进行分析。

小波分析发现，近60年，花园口站存在2-4年、912 年、27-30年的周期, 强信号分别存在于：20世纪 50 年代中期到 70 年代、60年代初期到 70年代中期、 80 年代。利津站存在2-4年、9-12年的周期, 强信号分别 存在于：20世纪50年代末期到 60 年代末期、50年代初 期到 80年代中期。两站均是 2-4年为第一主周期。这 表明黄河下游径流存在较显著的年际和年代际变化特 征。

\section{1. 年代际变化}

通过计算，两站近 60 年（1951-2012 年）的径流 平均值分别为： $374.5 \times 108 \mathrm{~m}^{3} 、 302.9 \times 108 \mathrm{~m}^{3}$ 。表 1 给出了 1951-2012 年花园口站和利津站各年代径流的 平均值以及距平百分比, 20 世纪 50 年代和 60 年代, 两站平均径流均大大高于各自多年平均值, 属于丰水 年份, 特别是 60 年代, 两水文站年平均径流均达最 高值, 分别为 $505.9 \times 108 \mathrm{~m}^{3} 、 501.4 \times 108 \mathrm{~m}^{3}$ 。70 年 代, 两站平均径流均下降到多年平均值附近, 80 年 代, 花园口站平均径流量增加到高于多年平均值, 而 利津站则有所减少, 略低于多年平均值, 到 90 年 代, 利津站年平均径流达最低值, 仅为 $143.6 \times 108$ $\mathrm{m}^{3}$, 与 60 年代相比减少了 $71.4 \%$ 。花园口站 21 世纪 的平均径流相比 60 年代减少了 $50.3 \%$, 利津站 21 世 纪与 20 世纪 90 年代相比则略有上升。根据表 1 各年 代距平百分比并对应前文的丰枯划分标准以及黄河流 域气温统计分析(具体见下文)可知, 黄河下游在气候 相对冷的 50 年代、 60 年代处于丰水期, 70 年代、 80 年代处于平水期, 而 90 年代以后则进入枯水期, 与 气温增暖的时期相同，现在正处于枯水期。

Mann-Kendall 的秩次相关检验法可以检验序列的 突变特点, 通过此方法进行的检验结果表明: 上述水 文站的径流序列表现出突变特征, 其中花园口站的径 流突变发生在 1985 年, 利津站的径流突变发生在 1978 年, 这表明上述水文站出现的径流减少可能是其 年代际尺度上的一种转折性或突变现象。 
表 1 黄河下游各年代径流量 $\left(\mathrm{R} / 10^{8} \mathrm{~m}^{3}\right)$ 及距平百分比 $(\%)$

Table 1 The decadal runoff and its anomaly in the downstream areas of the Yellow River

\begin{tabular}{|c|c|c|c|c|c|c|c|c|c|c|c|c|}
\hline \multirow[t]{2}{*}{ 测站 } & \multicolumn{2}{|c|}{ 1951-1959年 } & \multicolumn{2}{|c|}{ 1960-1969年 } & \multicolumn{2}{|c|}{ 1970-1979 年 } & \multicolumn{2}{|c|}{ 1980-1989 年 } & \multicolumn{2}{|c|}{$1990-1999$ 年 } & \multicolumn{2}{|c|}{ 2000-2012 年 } \\
\hline & $\begin{array}{l}\text { 径流 } \\
\text { 量 }\end{array}$ & $\begin{array}{c}\text { 距平 } \\
\text { 百分比 }\end{array}$ & $\begin{array}{l}\text { 径流 } \\
\text { 量 }\end{array}$ & $\begin{array}{c}\text { 距平 } \\
\text { 百分比 }\end{array}$ & $\begin{array}{l}\text { 径流 } \\
\text { 量 }\end{array}$ & $\begin{array}{c}\text { 距平 } \\
\text { 百分比 }\end{array}$ & $\begin{array}{l}\text { 径流 } \\
\text { 量 }\end{array}$ & $\begin{array}{c}\text { 距平 } \\
\text { 百分比 }\end{array}$ & $\begin{array}{l}\text { 径流 } \\
\text { 量 }\end{array}$ & $\begin{array}{c}\text { 距平 } \\
\text { 百分比 }\end{array}$ & $\begin{array}{l}\text { 径流 } \\
\text { 量 }\end{array}$ & $\begin{array}{c}\text { 距平 } \\
\text { 百分比 }\end{array}$ \\
\hline 花园口 & 487.6 & 29.2 & 505.9 & 34.5 & 381.6 & 1.5 & 411.7 & 9.50 & 256.9 & -31.7 & 251.3 & -38.4 \\
\hline 利 津 & 476.8 & 56.9 & 501.4 & 63.7 & 311.2 & 1.6 & 285.9 & -6.7 & 143.6 & -53.1 & 158.9 & -54.0 \\
\hline
\end{tabular}

\section{2. 年际变化特征}

近 60 年黄河下游的径流量总体呈现下降趋势。 这与上中游年降水量减少、用水量增加有关。但在 2002 年以后又呈现出有一定的转折上升趋势。花园口 站年径流最大值（861.4 亿立方米）出现在 1964 年, 最小值（142.6 亿立方米）出现在 1997 年, 最大、最 小值之比为 6.04 。利津站的最大、最小值出现年份与 花园口站一致, 其极值比达 42.5。表明黄河流域下游 径流的年际振荡现象十分显著, 且越靠近下游越剧 烈。
近 60 年的径流气候变化倾向率（表 2) 表明: 夏季和秋季径流的递减率大，而冬季则是最小。且利 津站每一季节的减少量都比位于其上游的花园口站更 多。两站四季径流变化（图 1) 分析表明：2002 年之 前，各季节的径流都呈现一致的下降趋势；从 2002 年左右开始，春季、夏季、冬季两站的径流均呈现上 升趋势, 且夏季增加更为明显, 秋季则呈减少趋势。 由此推知, 21 世纪黄河下游径流的上升趋势主要是由 于夏季径流的增加导致, 该现象与 20 世纪末期以来 全球气候变暖的趋势有所缓和是一致的（沈永平和王 国亚，2013）。

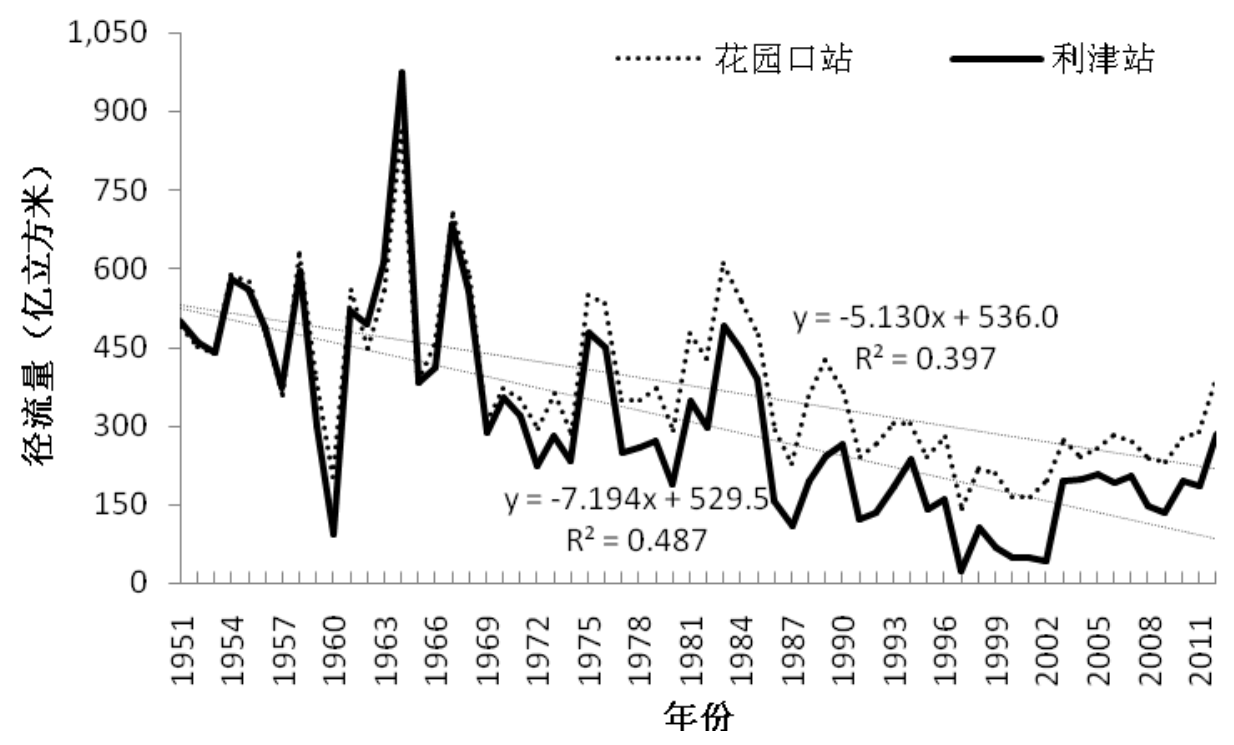

图 1 黄河花园口站、利津站 1951-2012 年平均径流量(亿立方米)

Fig.1 The annual runoff in Huayuankou and Lijin Hydrologic Stations in the Yellow River basin during 1951 $2012\left(10^{8} / \mathrm{m}^{3}\right)$

表 2 黄河下游径流 $\left(10^{8} \mathrm{~m}^{3} / 10 \mathrm{a}\right)$ 变化趋势

Table 2 Annual and seasonal changes of runoff in the downstream areas of the Yellow River $\left(10^{8} \mathrm{~m}^{3} / 10 \mathrm{a}\right)$

\begin{tabular}{|l|l|l|l|l|l|}
\hline 测站 & 全年 & 春季 & 夏季 & 秋季 & 冬季 \\
\hline 花园口 & -51.3 & -4.48 & -18.9 & -22.6 & -1.9 \\
\hline 利 津 & -71.9 & -13.6 & -26 & -30.2 & -5.7 \\
\hline
\end{tabular}


利用累积距平方法对每个站年径流分析表明：两 站径流变化大致可分为三个阶段 (图中灰色虚线划分 的三个区域）：相对多水期、相对平稳期和显著下降 期。两站第一阶段的时间段基本一致, 均在 20 世纪 50 年代和 60 年代; 第二阶段略有差别, 花园口站是 在 70 年代和 80 年代, 利津站则是在 70 年代到 80 年 代中期; 第三阶段花园口站是在 90 年代之后, 利津 站是在 80 年代中期以后。由上可知, 1951 年以来, 黄河流域下游径流大体均经历了丰-正常-枯 3 个变化 阶段, 虽然两站丰枯变化的分界点有些差异, 但自 20 世纪 80 年代末 90 年代初以来持续偏枯的事实是可 以确定的, 上面分析得到的结论与采用丰枯等级划分 标准所得到的结果基本一致。

\section{3. 年内变化年内分配规律}

由于受降水、气温等气候要素季节性变化的影 响, 导致径流的补给也出现明显的季节性变化, 决定 了径流年内分配随季节的周期性变化和非均匀变化。 研究径流年内分配特征的方法主要包括: 月、季、汛 期-非汛期径流量占年径流量的百分比等。本文采用 变差系数来分析黄河下游径流的年内分配特征。

图 2 表明: 花园口站和利津站多年平均的径流年 内分配曲线 (虚线) 非常相似, 均为“双峰型”, 丰枯

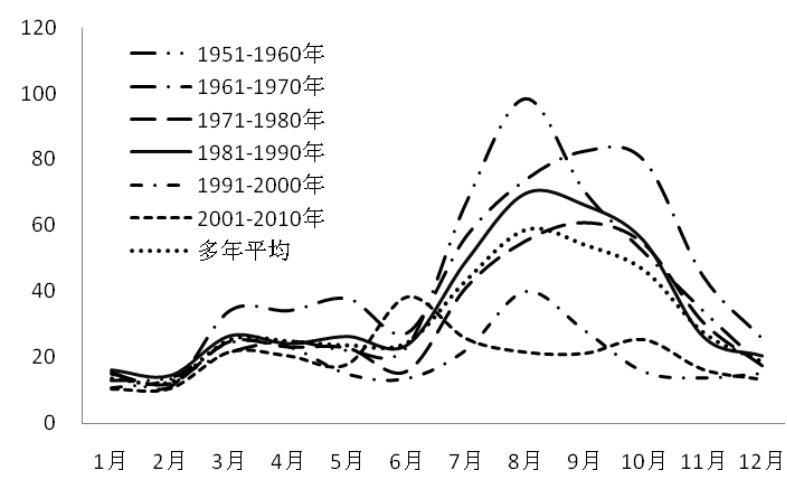

季节变化尤为明显。两站均在 8 月有一个较大峰值, 但是春汛水量都不是很大, 略不同的是, 花园口站在 春汛期的峰值稍比利津站明显一点。冬季径流量明显 低于其他季节，仅占全年总量的 $11.7 \%$, 全年径流量 基本上集中在 7-10 月份，占全年总量的 60.7\%。

20 世纪 50 年代, 两站径流年内分配呈现双峰结 构, 但春汛期的峰型坡度比较缓和, 而 8 月份的峰型 则很陡峭; 60 年代两站均呈现多峰型, 但春汛期的峰 型依旧很平缓, 利津站在 8 月和 10 月均有一个峰 值; 70 年代、 80 年代花园口站峰型特征与 60 年代的 类似, 只是 80 年代其中一个峰值提前了一个月, 落 在 8 月; 代利津站 70 年代也呈双峰型, 80 年代则则 是多峰型; 90 年代花园口站是 3 月和 8 月的双峰型, 利津站则是 8 月的单峰型; 进入 21 世纪后, 径流减 少明显, 花园口站峰值分布在 3 月、 6 月、 10 月, 利 津站峰值分布在 6 月、10月, 但 10 月的很平缓, 相 比于前面大多数年代, 两站夏季径流均有增加, 且出 现峰值, 这也进一步验证了上面近 10 年的径流增加 是由于夏季径流上升造成的结论。

另外, 通过比较两站各年代径流峰型曲线与多年 平均值曲线可以看出: 两站 90 年代 8 月份的峰值均 夹在 21 世纪后峰值之间, 且气候变暖后的 90 年代及 以后峰型远不及以前陡高, 明显低于多年平均值。

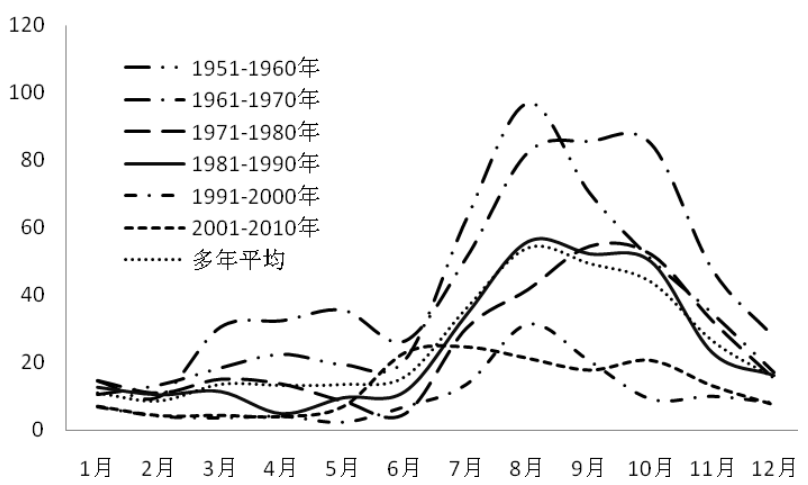

图 2 花园口站（左）、利津站（右）各年代径流年内分配曲线 $\left(10^{8} / \mathrm{m}^{3}\right)$

Fig.2 Monthly variations of the runoff for various decades at Huayuankou(left) and Lijin(right) Hydrologic Stations $\left(10^{8} / \mathrm{m}^{3}\right)$

径流变差系数是反映径流变化的参数之一。计算 得到近 60 年花园口站和利津站的月径流变差系数均 很大, 说明各月的年际丰枯变化均比较剧烈; 花园口 站的峰值在 6 月和 10 月, 利津站的峰值则在 5 月和 10 月, 这些月份的径流年际振荡尤为剧烈, 花园口站 夏季和秋季的径流变化多、最不稳定, 而利津站径流 则是春末和秋季 (尤其是春季) 最变化多端; 花园口 站春季的径流变差系数最小, 径流变化比较平缓, 而 利津站径流变差系数则是冬季最小, 且所有月份的值
都大于对应月份花园口站的值, 说明利津站径流年际 丰枯变化更为剧烈。

\section{3. 径流对气候因子的响应}

气候因子对水循环过程的影响是复杂和多层次的, 气候系统通过降水、气温、日照、风、相对湿度等因 子直接或间接地影响着水循环过程, 其中降水是最为 直接影响的因子, 气温等则是间接影响。通过统计近 60 年的降水、温度资料发现: 黄河流域多年平均降水 
量为 $507 \mathrm{~mm}$, 其中夏季的平均降水量最大, 达 293 $\mathrm{mm}$, 秋季次之, 春季降水量比秋季略小, 冬季则几 乎没有降水, 平均降水量仅为 $15 \mathrm{~mm}$; 多年平均温度 呈明显上升趋势, 其中冬季增温最为明显, 即暖冬现 象。

\section{1. 径流对降水的响应}

降水是径流的直接来源。黄河流域年降水线性 趋势和 5 年滑动平均曲线表明, 黄河流域年降水总体 呈弱的下降趋势,进入 21 世纪之后有增加的趋势。通 过计算各年代降水距平值, 发现降水表现出阶段性特 点: $50 、 60 、 70$ 年代的降水均是正距平, 降水偏多, 其中 50 年代距平值为 $27 \mathrm{~mm}$, 降水量最多; $80 、 90$ 年代均为负距平, 降水偏少; 进入 21 世纪之后, 降
水有增多趋势, 比多年平均值略低, 这种降水年代际 分型特点与径流的变化规律基本吻合。

对两站各时段径流序列与同期降水进行相关分 析(表 3)发现: 年平均降水量与两水文站年径流的相 关系数分别为 0.56 和 0.6 , 均超过了 0.01 的置信水 平。除冬季之外, 降水量与径流量在各时段均存在正 相关关系（通过显著性检验），秋季降水与径流相关 性最好, 夏季次之, 且夏季相关系数与秋季的相差不 大，但是冬季降水和径流的相关性没有通过显著性检 验, 这是因为, 冬季的降水本来就很少, 径流来源主 要靠地下水和上游的冰雪融水。总之, 降水与径流的 关系在汛期是较好的, 相反, 在非汛期 (特别是冬 季) 的关系则较差。

表 3 各时段径流量与降水、温度的相关系数

Table 3 Annual and seasonal correlation coefficients between precipitation temperature and runoff

\begin{tabular}{|c|c|c|c|c|c|c|c|c|c|c|}
\hline \multirow[t]{2}{*}{ 测站 } & \multicolumn{2}{|l|}{ 全年 } & \multicolumn{2}{|l|}{ 春季 } & \multicolumn{2}{|l|}{ 夏季 } & \multicolumn{2}{|l|}{ 秋季 } & \multicolumn{2}{|c|}{ 冬季 } \\
\hline & 降水 & 温度 & 降水 & 温度 & 降水 & 温度 & 降水 & 温度 & 降水 & 温度 \\
\hline 花园口站 & 0.56 & -0.64 & 0.34 & 0.48 & 0.5 & 0.17 & -0.35 & -0.41 & -0.48 & -0.31 \\
\hline 利津站 & 0.6 & -0.67 & 0.3 & 0.5 & 0.52 & 0.05 & -0.49 & -0.34 & -0.47 & -0.56 \\
\hline
\end{tabular}

注: $\mathrm{r}_{0.05}=0.25 ; \mathrm{r}_{0.01}=0.32$.

\section{2. 径流对温度的响应}

在气候变化背景下, 近 60 年来, 黄河流域气温 总体呈上升趋势, 增温速率约 0.29/10a(图 3a), 高于 全国平均气温的增温趋势。

从图 3(b)看出: 20 世纪 80 年代以后, 增温趋势 明显, 90 年代以后这种增暖趋势大大超过了显著性水 平 0.05 临界线, 甚至超过了 0.001 显著性水平 $\left(\mathrm{U}_{0.05}=1.96, \mathrm{U}_{0.001}=2.56\right)$ 。根据 UF 与 $\mathrm{UB}$ 交线的位置, 确定气温突变年份是 1988 年。

统计分析表明, 黄河流域气温变化大致可分为两 个阶段: 20 世纪 50 年代到 80 年代中期, 黄河流域气 温比较平稳; 80 年代中后期开始气温呈上升趋势, 90 年代以后升温明显加快, 达 0.36/10a。同样地, 温度 距平百分率曲线的振荡比径流的弱得多, 甚至比降水 的幅度还小。表 4 给出了黄河流域年平均气候倾向率 变化情况, 各季温度与全年温度变化趋势一致, 其中 冬季的升温幅度最大 $(0.45 / 10 \mathrm{a})$ 。冬季气温的大幅度升 高势必对黄河流域凌情造成影响（杨特群等, 2009）。分析各时段温度与两站径流的相关系数(表 4) 发现: 两站径流与温度在全年和各个季节均存在明显 的负相关关系（通过了显著性检验）, 说明黄河流域 温度升高对径流减少有着不可忽视的影响。

结合降水和温度两个因子和两站径流的变化可以 发现: 气温突变增暖之后的 20 世纪 90 年代, 黄河流 域的气候变得暖而干燥, 与此同时, 径流也显著减
少, 甚至出现断流, 但 21 世纪之后, 降水有所增 加, 气候向着暖湿化方向发展, 所以径流量也随着增 加。

\section{4. 降水、气温因子对径流变化的贡献分析}

为进一步定量分析两气候因子在径流变化中所占 的比重, 本文运用 $\mathrm{Lu}$ 等 (2010) 所使用的方法, 利 用月径流资料和月气象资料，计算降水、气温两个主 要气候因子对花园口站和利津站径流变化的贡献, 以 此来定量分析气候因子对径流变化的贡献。径流的自 然变化 $(\mathrm{S})$ 主要受降水 $(\mathrm{P})$ 和温度 $(\mathrm{T})$ 的影响, 故径流的 变化可以用下式来解释: $\Delta S=\frac{\partial S}{\partial P} \Delta P+\frac{\partial S}{\partial T} \Delta T$ ，其 中 $\frac{\partial S}{\partial P}, \frac{\partial S}{\partial T}$ 分别是降水和温度对径流变化的贡献率, 近似取为对应因子的多元回归系数。先利用气候因 子、径流的各月值计算出贡献率, 并将此贡献率与各 因子标准差相乘，即可得到每个气候因子对径流年内 变化的贡献值, 文中所指“正贡献”是指径流因气候因 子的变化而增加, “负贡献”是指径流因气候因子的变 化而减少。 

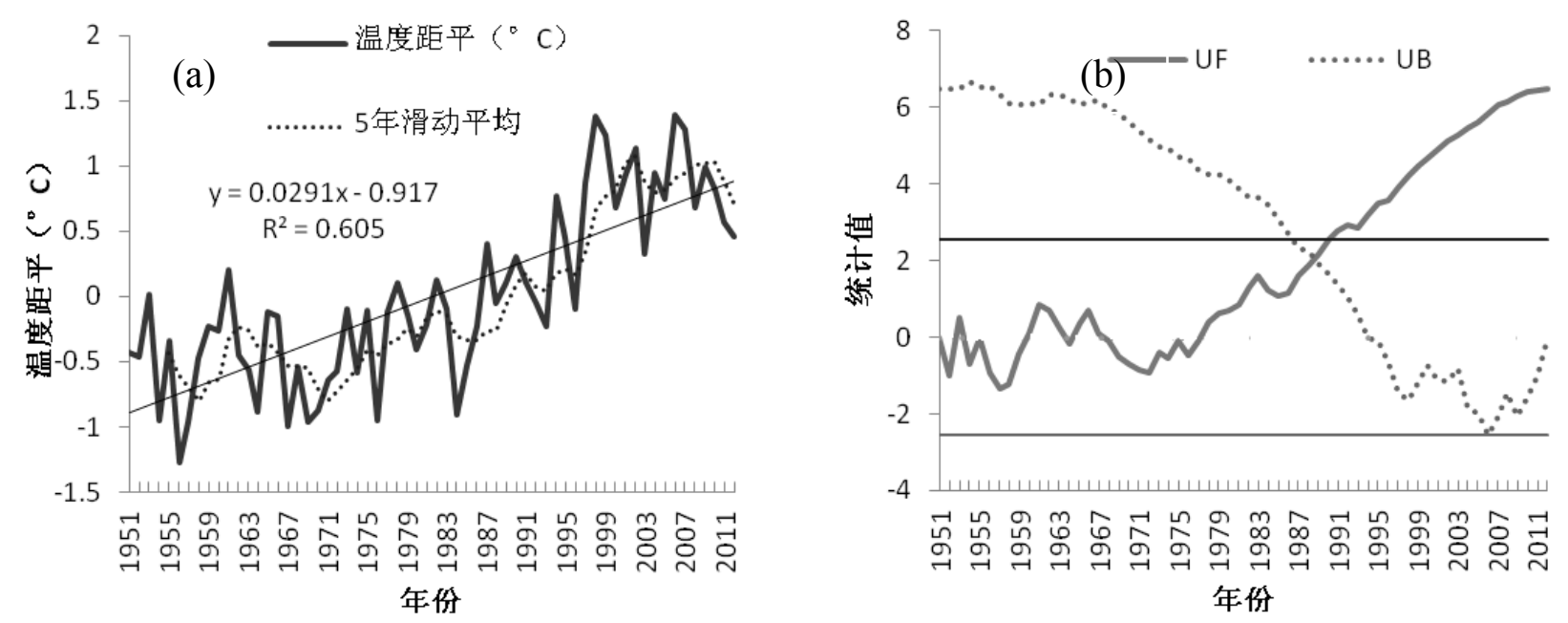

图 3 黄河流域年平均气温变化(a)和 MK 检验(b)

Fig.3 Annual average variation of temperature in the reaches of the Yellow River and MK test

表 4 黄河流域平均气温气候倾向率(/10a)

Table 4 Tendency rates of average temperature in the reaches of Yellow River(/10a)

\begin{tabular}{|l|l|l|l|l|l|}
\hline 因子 & 全年 & 春季 & 夏季 & 秋季 & 冬季 \\
\hline 温度 & 0.29 & 0.32 & 0.14 & 0.45 & 0.24 \\
\hline
\end{tabular}

分析计算结果发现（图 4）：降水和气温因子对 径流的变化有所不同, 对这两个水文站而言, 降水对
径流的贡献以正贡献为主, 温度对径流的贡献以负贡 献为主, 且都是在夏季和秋季最为明显, 冬季和春季

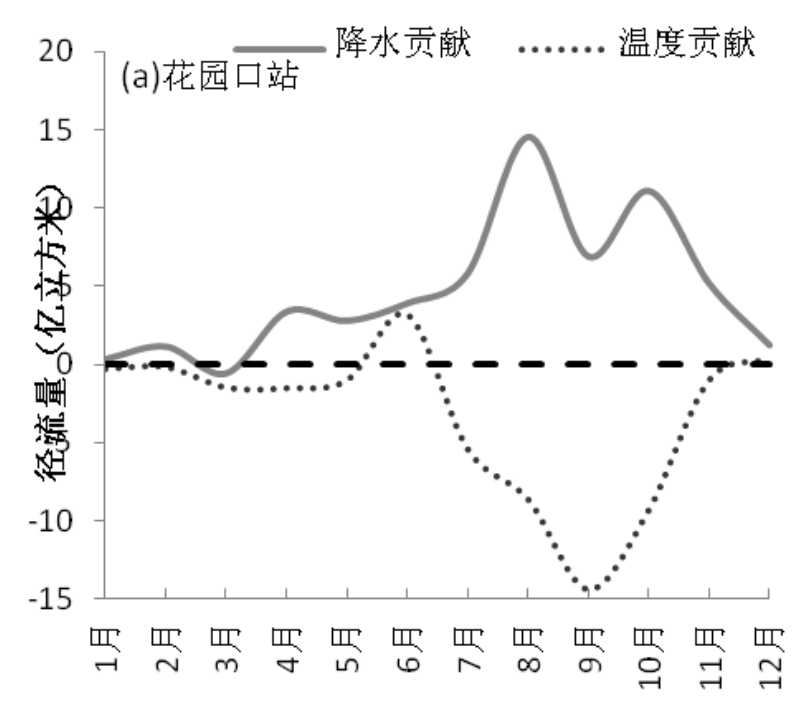

月份

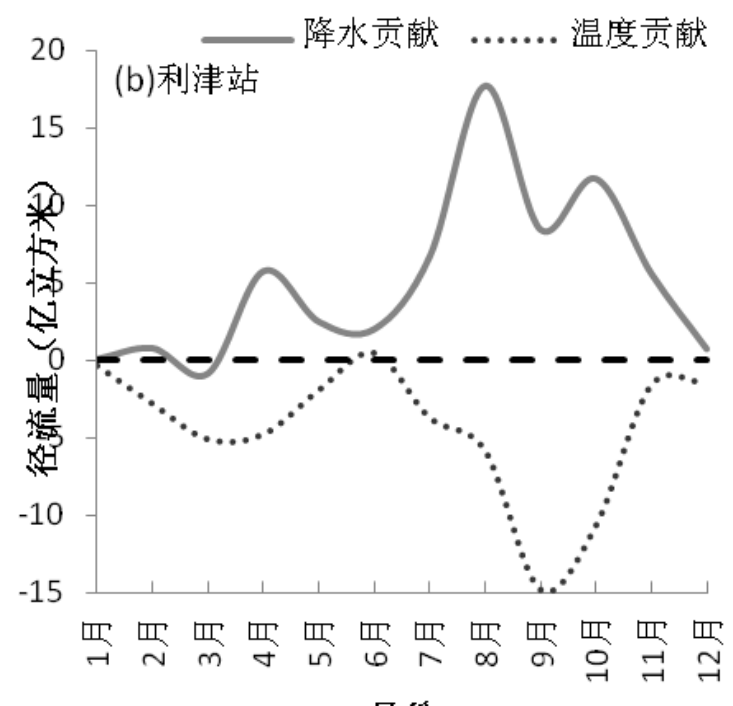

月份

图 4 黄河流域降水和温度对径流的贡献 $\left(10^{8} / \mathrm{m}^{3}\right)$

Fig.4 Monthly variations of the contributions of precipitation and temperature to runoff in the downstream areas of the Yellow River $\left(10^{8} / \mathrm{m}^{3}\right)$ 
的贡献相对较弱。在降水对径流的正贡献期间, 两 个站都表现出明显的双峰型特征: 其中全年最高峰 值点都出现在 8 月，7-11 月期间花园口、利津两站 的正贡献分别达 14.6 亿立方米、 17.7 亿立方米; 次 峰值点均出现在 10 月, 两站的正贡献分别为 11.1 亿 立方米、11.7 亿立方米; 两站温度对径流的负贡献 都呈现单峰型特征, 在 9 月份的负贡献绝对值均达 到最大, 分别为-14.4 亿立方米和-14.8 亿立方米, 刚 好对应两站降水正贡献的谷值, 即降水对径流影响 最弱时温度对径流影响达最强。花园口、利津两站 全年降水对径流的正贡献平均值分别是 4.6 亿立方 米和 5.1 亿立方米, 温度对径流的负贡献平均值分 别是-3.3 亿立方米和- 4.4 亿立方米。

\section{5. 结论与讨论}

本文根据 1951-2012 年的气象和水文观测资 料, 对黄河流域下游的径流变化规律、径流对降 水、气温因子的响应以及这种响应随时间的变化特 征和降水、气温因子对径流的贡献等问题进行了统 计分析和特征诊断, 揭示了一些有意义的现象特 征, 主要研究结果:

(1)近 60 年来, 黄河流域下游径流量总体呈现 下降趋势, 表现出突变特征： 20 世纪 60 年代以前处 于丰水期, 70 年代和 80 年代处于平水期, 90 年代 以后进入枯水期, 但目前是有由枯转丰的趋势; 径 流年际变化振荡剧烈, 且呈现偏态分布, 枯水年份 不仅发生概率高, 且持续性好, 最长连枯年份可达 21 年之久。

(2)黄河流域多雨期主要集中在 20 世纪 50 60 年 代以及 70 年代, 80 年代和 90 年代均为少雨期, 进 入 21 世纪之后降水量有增多的趋势; 气温一直呈增 加趋势, 并在 1988 年呈现突变特征, 冬季升温率最 高, 即暖冬现象明显; 气候因子与径流量在有的时 段呈同期变化或者先于径流量变化。

(3) 无论是年径流还是各季节径流与同期降水、 气温因子的相关性都是不稳定的, 且这种响应随时 间呈非平稳变化; 径流对降水量变化的响应比对温 度变化的响应更敏感。

(4) 降水对径流以正贡献为主, 温度对径流以负 贡献为主, 且都是在夏季和秋季最明显, 冬季和春 季的贡献相对较弱。

\section{参考文献}

Grinsted J C and Moore S. J, Application of the cross wavelet transform and wavelet coherence to geophysical time series. Nonlinear Processes in Geophysics 11(2004), 561566.

郝振纯, 王加虎, 李丽, 等.气候变化对黄河源区水资源 的影响. 冰川冻土 28(1) (2006), 1-7.

蓝永超, 文军, 赵国辉, 等. 黄河河源区径流对气候变化 的敏感性分析.冰川冻土 32(1) (2010), 175-182.

刘吉峰, 范旻昊. 黄河流域气候变化特点及趋势. 中国水利 学会 2010 学术年会论文集,2010.

Lu Er,Take E S,Manoj. The relationships between climatic and hydrological changes in the upper Mississippi River basin: A SWAT and multi-GCM study. Journal of Hydrometerorology, 11 (2010), 437-451.

徐东霞.近 50 年嫩江流域径流变化特征及其影响因素分析. 北京: 中国科学院研究生院.2008.

Parry M, Canziani O, Palutikof J, et al. Climate Change 2007:Impacts, Adaptation and Vulnerability Contribution of Working Group IIof the Forth Assessment Report of the Intergovernmental Panel on Climate Change. (Cambridge, UK: Cambridge University, 2007) p.122.

沈永平, 王国亚.IPCC 第一工作组第五次评估报告对全球 气候变化认知的最新科学要点. 冰川冻土, 35(5) (2013), 1068-1070.

杨特群, 饶素秋, 陈冬伶. 1951 年以来黄河流域气温和降 水的变化特点分析.人民黄河, 31(10) (2009), 76-77. 